Article

\title{
The Influence of Managerial Mindfulness on Innovation: Evidence from China
}

\author{
Yuanyuan $\mathrm{Hu}^{1, *}$, Xiaoping Zhao ${ }^{2} \mathbb{1 0}$ and Yang Chen ${ }^{3}$ \\ 1 School of Economics and Management, Tongji University, Shanghai 200092, China \\ 2 Antai College of Economics and Management, Shanghai Jiao Tong University, Shanghai 200030, China; \\ zhaoxiaoping@sjtu.edu.cn \\ 3 Department of Biochemical Engineering, University College London, London WC1E 6BT, UK; \\ yang.chen.18@ucl.ac.uk \\ * Correspondence: huyuanyuan@tongji.edu.cn or 1710032@tongji.edu.cn; Tel.: +86-21-65981669
}

Received: 3 April 2019; Accepted: 20 May 2019; Published: 22 May 2019

check for updates

\begin{abstract}
This study attempts to investigate the influence of managerial mindfulness on firm innovation. Managerial mindfulness is defined as a collective psychological state shared by top management team (TMT) members and represents their collective attention to present-moment events and experiences. Drawing from two psychological mechanisms of mindfulness, we argue that managerial mindfulness can positively affect R\&D intensity-a proxy for firm innovation. The first psychological mechanism is that mindfulness facilitates self-regulation. By facilitating self-regulation, managerial mindfulness enables TMT members to behave less opportunistically and act in a less self-serving manner. Therefore, TMT members are concerned about the shareholders' interests in long-term value creation and hence are willing to take more risk such as investing more in $R \& D$. The second psychological mechanism is that mindfulness facilitates goal-pursuit, especially for intrinsic goals. Mindful TMT members are autonomously motivated to pursue goals that are more satisfying, persist for longer durations, and show greater success than goals that are extrinsically motivated; mindful TMT members are likely to view R\&D as an intrinsic goal to pursue. In addition to the main effect, this study also examines several moderators and suggests that the positive relationship between managerial mindfulness and R\&D intensity is moderated by firm age, slack resources, and past financial performance. Specifically, this relationship becomes weaker when a firm grows older and the firm has better past financial performance, while it is stronger when a firm has greater slack resources. To empirically test our hypotheses, we rely on a sample of Chinese listed companies and collect data from the China Stock Market and Accounting Research (CSMAR). Feasible generalized least squares (FGLS) regression is adopted due to the presence of significant autocorrelations and heteroskedasticity. The empirical analyses provide full support for our hypotheses. Therefore, this study contributes to literature of mindfulness, as well as studies on TMT's influence on firm strategy and decision-making.
\end{abstract}

Keywords: mindfulness; managerial mindfulness; innovation; R\&D intensity

\section{Introduction}

Innovation, as a major strategy for enterprises to build and maintain their sustainable competitive advantages, has been a hot issue in management and economic studies [1-3]. It has been shown that innovation is an essential driver for corporate sustainable development [2,4]. Among them, many researchers pay more attention to the research on the influencing factors of enterprise R\&D investment intensity [2]. At present, there are two main types of research on antecedents of $R \& D$ investment: one is from the perspective of external environment of enterprises, such as 
macro-environment, institutional environment, cultural environment, etc. [5,6], the other is from the internal micro-environment of enterprises, such as board structure, ownership structure, and advertising investment [7-9]. However, most of them study the influencing factors of R\&D investment from the perspective of objective factors. Few scholars study the subjective characteristics of executive.

Mindfulness, an ancient and mysterious way of spiritual practice, is quietly sweeping the business world, changing the mental models of managers and becoming an important source of competitive advantage for enterprises. Mindfulness originated from the ancient wisdom of the East and has over 1000 years of history. In China, it has been mentioned many times in its early days. For example, "Genuine knowledge acquired, thoughts purified; thoughts purified, hearts rectified; hearts rectified, personalities cultivated; personalities cultivated, families regulated; families regulated, the states well governed; the states well governed, the whole world will be in peace and tranquil." In The Great Learning, one of the Four Books; "Governing Shu by Tao" in Lao Tzu's Tao Te Ching, which means that if "the Tao" is not correct and the idea is not sincere, the Shu (management method) is also confused and the top managers become more and more stressed because of this. The philosopher Tsang said, "I daily examine myself on three points: whether, in transacting business for others, I may have been not faithful; whether, in intercourse with friends, I may have been not sincere; whether I may have not mastered and practiced the instructions of my teacher." In the age of fragmentation, top managers also tend to have discrete and non-focused attention. Therefore, through the practice of mindfulness, managers can not only make their attention more focused, but also more timely and keen to detect the wandering of thinking, so that they can work more efficiently, reduce errors and accidents caused by not paying enough attention to the current events, and thus help managers to keep peace of mind within a complex dynamic environment and enhance the rationality of management decisions [10]

As noted by Good et al. (2016) [11] (p.115), "Interest in mindfulness, defined in basic terms as present-centered attention and awareness, is surging." However, mindfulness is primarily, if not exclusively, viewed as an individual's psychological state $[12,13]$ or a type of personal traits $[14,15]$. In recent years, although some scholars have begun to study collective mindfulness, there are few studies in the field of organizational management. In this paper, we argue that mindfulness can be a collective-level psychological state of an organization or a team. We specifically focus on mindfulness shared by members of the top management team (TMT) of a firm-hereby called 'managerial mindfulness'. In this study, managerial mindfulness refers to a collective psychological state that is shared by TMT members. In other words, managerial mindfulness reflects TMT members' attention paid to internal and external present-moment states, events, and experiences. In general, our conceptualization of managerial mindfulness as a collective psychological state is closer to the classic Buddhist philosophy: attention to the present [16]. In addition, we emphasize that managerial mindfulness is a relatively enduring, stable, and shared property of a TMT.

More importantly, our study attempts to address whether and how managerial mindfulness affects firm innovation. Previous studies have shown that firm strategy and decision-making are determined collectively by TMT members [17] and that a set characteristics of TMT members (e.g.; TMT tenure, TMT demographics, and TMT diversity) are able to influence firm strategy and decision-making [18-22]. Our study adds to this literature that managerial mindfulness as a collective psychological state shared by TMT members can also influence firm strategy and decision-making. Specifically, we examine the influence of managerial mindfulness on R\&D intensity—a proxy of firm innovation [23]. R\&D plays a critical role in organizational adaptation and evolution and is a key determinant of firm long-term value and corporate sustainable development $[2,4,24,25]$. However, TMT members are reluctant to make investments in R\&D because TMT members are loss-averse and they give more weights to the potential loss than the potential gains incurred by R\&D in short-term. However, in this paper, we propose that two psychological mechanisms of managerial mindfulness enable more mindful TMT members to invest more in R\&D.

The first psychological mechanism is that mindfulness facilitates self-regulation [26,27]. By facilitating self-regulation, managerial mindfulness enables TMT members to behave less 
opportunistically and act in a less self-serving manner. Rather, TMT members act more in a manner more fitting of stewardship [28]. Therefore, TMT members are concerned about the shareholders' interests in long-term value creation and hence are willing to take more risk such as investing more in $R \& D$. The second psychological mechanism is that mindfulness facilitates goal-pursuit, especially for intrinsic goals [12,29]. Mindful TMT members are autonomously motivated to pursue goals that are more satisfying, persisting for a longer duration, and show greater success than goals that are extrinsically motivated [30]. Because R\&D is a critical determinant of a firm's long-term success and survival, mindful TMT members are likely to view $R \& D$ as an intrinsic goal to pursue. Thus, mindful TMT members are likely to invest more in R\&D. In a summary, we propose two psychological mechanisms to explain why more mindful TMT members are less loss-averse than less mindful TMT members and, therefore, more mindful TMT members are likely to invest more in R\&D activities.

In general, we suggest that managerial mindfulness can have a positive impact on R\&D intensity. Furthermore, we show that the positive influence of managerial mindfulness on can be moderated by three firm characteristics including firm age, slack resources, and past financial performance. Using a sample of Chinese listed firm, we provide empirical evidence to our arguments. Our study can make two contributions. First, it contributes to the literature of TMT's impact on firm strategy and decision-making. We add to this literature by showing that managerial mindfulness as a collective psychological state of TMT can influence firm innovation-proxied by R\&D intensity in this study. Second, our study contributes to the literature of mindfulness by conceptualizing it as a collective-level construct. Previous studies mainly describe mindfulness as an individual's psychological state or a type of personal traits [11]. Few studies examine mindfulness from a collective perspective (see Weick et al.; 1999 as an exception) [31]. However, our conceptualization of managerial mindfulness as a collective psychological state of TMT members is largely different from the highly influential conceptualization of collective mindfulness by Weick et al. (1999) [31], who define collective mindfulness as mindful organizing characterized by several interrelated processes at multiple organizational levels. Instead, our study shows that mindfulness does not matter to an individual, but also can collectively influence decision-making of a group or a firm.

This paper proceeds as follows. In Section 2, we review the literature and develop research hypotheses. Section 3 describes our data collection procedure and variable construction and outlines the empirical method used to investigate the hypotheses. Section 4 presents the results and a discussion of the empirical analysis. Section 5 concludes, offering interesting implications and the limitations of the findings.

\section{Literature Review and Research Hypothesis}

\subsection{Defining Managerial Mindfulness}

As noted, previous studies mostly view mindfulness as an individual's psychological state or a type of personal traits. In this literature, mindfulness is defined as a "receptive attention to and awareness of present events and experience" [32] (p.212). This is because those studies are largely drawn from the classic Buddhist philosophy of mindfulness, which emphasizes "clear-minded attention to, and awareness of what is perceived in the present" [11] (p.116). In fact, mindfulness has been a central term in Buddhist mental training for many years, and in recent years, firms such as Google have developed training programs of mindfulness to improve employees' functioning and performance [33-36]. Overall, there are more than 4,000 scholarly articles on this topic [37]. Weick and Roberts (1993) introduced the concept of mindfulness into the management literature, although their conceptualization of mindfulness as cognitive flexibility and attention to novelty has diverged from the classic Buddhist philosophy [38]. In short, individual mindfulness reflects a person's "mental state with the characteristics of present-focused awareness and attention" [39] (p.24).

In this study, we study managerial mindfulness-defined as TMT members' shared psychological state in which attention is paid to internal and external present-moment events. This definition 
emphasizes TMT members' collective attention to external and internal present-moments states, events, and experiences. In other words, managerial mindfulness represents a present-moment focused state of collective consciousness. In this view, managerial mindfulness differs from managerial attention [40] in that attention itself does not become mindful until attention is coupled with and monitored by an apprehension of the current state of the [41]. Managerial mindfulness as a collective construct in our study departs from a highly influential conceptualization of collective mindfulness by Weick et al. (1999) [31]. In their work, collective mindfulness refers to mindful organizing, which comprises five interrelated processes at multiple organizational levels: preoccupation with failure, reluctance to simplify interpretations, sensitivity to operations, commitment to resilience, and deference to expertise. While Weick et al. (1999) use collective mindfulness to explain how high-reliability organizations avoid catastrophe and perform in a nearly error-free manner under trying conditions [31]; our conceptualization of managerial mindfulness is closer to the classic Buddhist tradition and makes managerial attention to present-moment events more central. However, both Weick et al.'s (1999) conceptualization and our definition emphasize that collective mindfulness is a relatively enduring, stable, and shared property of an organization or a group [31,42].

\subsection{Influence of Managerial Mindfulness on RED Intensity}

Generally, this study attempts to understand whether managerial mindfulness influences on firm strategy and decision-making. To answer this question, we specifically examine the impact of managerial mindfulness on R\&D intensity-a proxy of firm risk-taking. R\&D plays a critical role in organizational adaptation and evolution. In order to respond to threats and opportunities posed by environmental changes, top executives like TMT members allocate resources to R\&D activities to explore alternatives and novel solutions [24,25]. In this view, $R \& D$ activities are important to organizational learning, innovation, competitive advantages, and long-term success [43,44]. Despite its importance to firm long-term performance and survival, TMT members are reluctant to invest in R\&D because, in short-term, R\&D often incurs substantial loss if R\&D projects fail and, in fact, the probability of R\&D projects failing can be as high as $40-90 \%$ [45-47]. Although R\&D also has the potential to largely improve firm performance, TMT members are more concerned about the loss potentially incurred by R\&D failures rather than the gains potentially made by R\&D success [23]. In addition, TMT members give more weight to potential loss than to potential gains when they compare those potential outcomes of R\&D [23]. In summary, TMT members are loss-averse and they are reluctant to investing in $\mathrm{R} \& \mathrm{D}$, which is inconsistent with shareholders' interests in long-term value maximization.

We argue, however, that more mindful TMT members are less loss-averse than less mindful TMT members are. Therefore, more mindful TMT members are likely to invest more in R\&D activities. That is, managerial mindfulness can have a positive impact on R\&D intensity. Below, we propose two psychological mechanisms drawn from previous studies on mindfulness to explain why managerial mindfulness could positively affect R\&D intensity.

The first psychological mechanism is that mindfulness facilitates self-regulation [26,27]. Experimental studies show that mindfulness training can develop individuals' self-regulatory capacities [48]. A few studies also demonstrate that mindfulness reduces automatic responses to external stimuli through its impacts on self-regulation [27,49]. As managerial mindfulness facilitates self-regulation, TMT members will behave less opportunistically and act in a less self-serving manner. Instead, TMT members act more in a stewardship manner [28]. Therefore, TMT members are concerned about the shareholders' interests in long-term value creation. TMT members are willing to take more risk (e.g.; invest more in $\mathrm{R} \& \mathrm{D}$ ) in order to maximize long-term firm value, even though they know such risk-taking may result in substantial loss in short-term. That is, managerial mindfulness can have a positive influence on TMT members' risk-taking behaviors such as R\&D investments, because managerial mindfulness facilitates self-regulation of TMT members, which in turn makes TMT members behave less opportunistically and act in a less self-serving manner and enables them to behave in a stewardship manner. 
The second psychological mechanism is that mindfulness facilitates goal-pursuit, especially for intrinsic goals [12,29]. One intuitive idea of mindfulness is that attention to present-moment events and experience may be at odds with the future orientation of goal-pursuit. In fact, it is observed from experiments that mindfulness supports goal-pursuit through improved attentional and motivational properties [12,29]. In addition, brain image research indicates that individuals that are more mindful are less motivated by extrinsic rewards like money [50]. Together, these studies suggest that mindfulness is not related with passivity. Instead, mindfulness is associated with autonomous motivation. Therefore, individuals that are more mindful are driven by intrinsic goals that are perceived by themselves as important, valued, or enjoyable. From this perspective, mindful TMT members are autonomously motivated to pursue goals that are more satisfying, persisting for a longer duration, and show greater success than goals that are extrinsically motivated [30]. Given that R\&D is a critical determinant of a firm's long-term success and survival, mindful TMT members are likely to view $R \& D$ as an intrinsic goal to pursue. In contrast, mindful TMT members are less concerned about the short-term loss that is potentially incurred by $R \& D$ failures, because they are not motivated by either extrinsic rewards like short-term gains or extrinsic punishments such as short-term loss. Therefore, mindful TMT members are likely to invest more in R\&D, suggesting a positive influence of managerial mindfulness on R\&D intensity.

In summary, we propose two psychological mechanisms to show that managerial mindfulness is positively related with R\&D intensity of a firm. Thus, the following hypothesis is proposed:

Hypothesis 1: Managerial mindfulness is positively associated with RED intensity.

\subsection{Moderating Role of Firm Characteristics}

Above, we have discussed why mindful TMT members are likely to invest more in R\&D. In this section, we will demonstrate how certain firm-level characteristics can moderate the positive association between managerial mindfulness and R\&D intensity.

\subsubsection{Firm Age}

The first firm characteristic is firm age, which may reflect the level of organizational rigidity of a firm [51]. Often, TMT members of older firms are more cognitive rigid than TMT members of younger firms because older firms have established routines that are the building blocks of firm capabilities [51]. In addition, older firms often become bureaucratic organizations [52]. Both established routines and bureaucratic structures can enhance an organization's rigidity [52]. When a firm grows older, its TMT members become more cognitively rigid. In other words, TMT members become less cognitively flexible. As a result, the influence of mindfulness will decrease because cognitive flexibility is a major manifestation of managerial mindfulness [53]. In addition, although it is true that smaller innovative companies such as the "hidden champions" maintain a distinctive level of innovation over a long time horizon, most of small companies are the same as large ones. That is to say, on the whole, most companies follow the above rules. In this vein, we suggest that the influence of managerial mindfulness on R\&D intensity will becomes weaker in older firms. Thus, the following hypothesis is proposed:

Hypothesis 2: The positive relationship between managerial mindfulness and RED intensity is moderated by firm age. Specifically, this relationship becomes weaker when a firm grows older.

\subsubsection{Slack Resources}

The second firm characteristic is slack sources, which reflects the stock of the excess resources available to a firm [54]. Usually, slack resources are accrued as a planned buffer or because of poor 
planning. Unlike firm age, which is positively associated with cognitive rigidity of TMT members, slack resources are negatively associated with cognitive rigidity but positively related with cognitive flexibility, because slack resources divert TMT members' attention from 'fire-fighting' to focus instead on flexible and expansive thinking [54]. As noted, cognitive flexibility is a major manifestation of managerial mindfulness. Therefore, the influence of mindfulness will become greater in firms with greater slack resources. As a result, we argue that the influence of managerial mindfulness on R\&D intensity will becomes stronger in firms with greater slack resources. Thus, the following hypothesis is proposed:

Hypothesis 3: Slack resources moderate the positive relationship between managerial mindfulness and RED intensity. Specifically, this relationship becomes stronger when a firm has greater slack resources.

\subsubsection{Past Financial Performance}

The third firm characteristic is a firm's past financial performance, which reflect how a firm performs in a past period. Past financial performance serves as a form of performance feedback to TMT members. The better a firm performs in a prior period, the more positive the performance feedback is perceived by TMT members. Similar to firm age, positive performance feedback increases cognitive rigidity of TMT members. The reason is that positive performance feedback signals to TMT members that they are in a safe situation and hence they do not to change the current situation [55]. Therefore, positive performance feedback is positively related with cognitive rigidity and negatively associated with cognitive flexibility. Again, the influence of mindfulness will decrease because cognitive flexibility is a major manifestation of managerial mindfulness [53]. In this aspect, we suggest that the influence of managerial mindfulness on R\&D intensity will become weaker when a firm performs better in a prior period. Thus, the following hypothesis is proposed:

Hypothesis 4: The positive relationship between managerial mindfulness and RED intensity is moderated by a firm's past financial performance. Specifically, this relationship becomes weaker when the firm has better past financial performance.

\section{Research Methodology}

\subsection{Sample Description and Data Resource}

The initial sample of this study composed all the Chinese manufacturing firms listed on the Shanghai stock market. We only used manufacturing firms for three reasons: First, using a single industry can control for the impact of industry differences. Second, the Industry Classification Standards 2012 indicates that manufacturing firms account for nearly $60 \%$ of all the listed firms in China. Third, R\&D intensity of Chinese listed firms is generally low and most firms that make R\&D investments and disclose information of R\&D investments in annual reports are manufacturing firms. Our sample consisted of an unbalanced panel of domestic firms over five years (2010-2014). There are several reasons for the sample starting in 2010 and ending in 2014. One important reason for the starting year of 2010 is that the Chinese government issued a new accounting regulation for listed companies in 2007. According to the new accounting regulation, $R \& D$ expenses of listed companies must be capitalized and reported in their annual reports. Before the release of the new regulation, $R \& D$ expenses could be treated as a part of operating costs and the information of R\&D expenses was not released in annual reports. Since the new regulation was issued in 2007, we chose 2010 as the starting year because some listed companies adopted it slowly and, until 2010, almost all listed companies adopted this regulation. Another important reason is the exogeneous shock of financial crisis during 2008-2009. Finally, we revised the starting year of our sample as 2010. As for the reasons why the sample ends in 2014, because China's economy has grown dramatically in the past decades, 
it is possible that the R\&D intensity of domestic firms in China changes over time. In fact, in order to capture this possible effect, we should include as much data as possible over time. However, it is very difficult to collect and process independent variables by hand. Therefore, following most scholars, we finally chose five years as our research period.

Most of the data used in this study (e.g.; R\&D intensity, financial performance, firm age, etc.) were obtained from the China Stock Market and Accounting Research (CSMAR), a database provides reliable data of Chinese listed firms. The validity and reliability of this database have been verified by many previous studies [56-60]. We supplemented the data from CSMAR database with data obtained directly from corporate annual reports. Moreover, the data of managerial mindfulness were obtained from corporate annual reports. After deleting outliers and missing values, the final sample was composed of 2,322 firm-year observations over the period from 2010 to 2014.

\subsection{Measures}

Dependent variable — Our dependent variable of R\&D intensity was measured with two variables. Firstly, it was a binary variable reflecting whether have an R\&D activity or not $(1=$ yes, $0=$ no). Secondly, it is a continuous variable according to previous studies, we used percentage of $R \& D$ expenditures to sales to measure the R\&D Intensity [61,62].

Independent variable-Our independent variable is managerial mindfulness. In experimental studies, mindfulness is induced by training programs or mediation practices $[63,64]$. Other studies use survey methods to measure mindfulness [65]. In this study, we used a novel method to measure managerial mindfulness. Specifically, we used textual analyses of corporate annual reports, an approach that have been used to measure managers' collective cognition and attention (for a review, see Ocasio, 2011) [40]. This form of textual analyses is based on the Sapir-Whorf hypothesis that individuals' psychological processes and thinking can be expressed through their languages. In this study, we contend that TMT members' shared psychological state in which attention is paid to internal and external present-moment events can be reflected by the language used in annual reports. Therefore, we can use textual analyses to capture the extent to which TMT member' attention that is paid to internal and external present-moment events. Following previous studies, we used word frequency to measure the level of managerial mindfulness.

To compute the word frequency, we adopted psycholinguistic approach suggested by Pennebaker et al. (2001) [66]. The critical task of this form of textual analyses was to identify the keywords that represented managerial mindfulness. To complete this task, we relied on the Simplified Chinese Linguistic Inquiry dictionary (SC-LIWC). The SC-LIWC was developed by Huang et al. (2012) based on the Traditional Chinese LIWC dictionary, which was developed based on the English LIWC2007 [67]. Previous studies have demonstrated that SC-LIWC works well for analyzing simplified Chinese texts [67]. The SC-LIWC dictionary includes a list of 25 words that reflect present-moment events (e.g.; “目前”, “现今”, “平时”). These 25 words were the keywords we used in our contextual analyses. After obtaining the list of keywords, we used word count text analysis program to search and then count the number of the keywords appearing in an annual report.

In order to compute the frequency of these keywords, we also needed the count of words associated with past-moment events and the count of words associated with future-moment events. The SC-LIWC dictionary includes a list of 26 words that reflect past-moment events (e.g.; “去年”, “刚才”, “昔日”) and a list of 22 words that reflect future-moment events (e.g.; “之后”, “即将”, “将来”). Similarly, we used the word count (SC-LIWC) text analysis program to search and then count the number of these keywords appearing in an annual report.

After obtaining the count of the keywords associated with present-moment events, past-moment events, and future-moment events, respectively, we proceeded to calculate two ratios of the frequency of present-moment events keywords. According to SC-LIWC, two separate indicators can be used to reflect present-, past-, or future-moment events in Chinese language. One is corresponding to the English LIWC2007 (e.g.; presentMi,t) and the other is unique to Chinese language (e.g.; tpresent $_{i, t}$ ) [67]. 
Therefore, we computed the two ratios of the frequency of present-moment events keywords using following formulas:

$$
\begin{aligned}
& \text { Mindfulness }_{i, t}^{1}=\frac{\text { tpresent }_{i, t}}{\text { tpast }_{i, t}+\text { tpresent }_{i, t}+\text { tfuture }_{i, t}} \\
& \text { Mindfulness }_{i, t}^{2}=\frac{\operatorname{presen} M_{i, t}}{\text { past }_{i, t}+\operatorname{present}_{i, t}+\text { future }_{i, t}}
\end{aligned}
$$

We also computed two other ratios of the frequency of present-moment events keywords as two alternatives, using the following formulas:

$$
\begin{aligned}
& \text { Mindfulness }_{i, t}^{3}=\frac{\text { tpresent }_{i, t}}{\text { tpast }_{i, t}+\text { tfuture }_{i, t}} \\
& \text { Mindfulness }_{i, t}^{4}=\frac{\text { present }_{i, t}}{\text { pastM }_{i, t}+\text { future }_{i, t}}
\end{aligned}
$$

As a result, we obtained four ratios of the frequency of present-moment events keywords. We found that the four ratios were highly correlated with each other and thus we standardized and aggregated them as a single indicator (alpha $=0.821$ ). The aggregated indicator was the mean of the standardized values of the four ratios. To check the robustness, we used the first ratio (i.e., Mindfulness ${ }_{i, t}^{1}$ ) as the independent variable in additional analyses and found that the empirical results did not substantially change from the empirical results using the aggregated indicator.

Moderators-Firm age was measured as the number of years since incorporation. Data of firm age were obtained from CSMAR. Slack resources were as the net cash flow scaled by total assets [68]. Past financial performance was measured as the average value of a firm's ROA in prior three years.

Control variables-In this study, we controlled for a set of variables. Prior studies have reported profitability, sales growth, financial resources, financial leverage, firm size, and state ownership may influence R\&D [69,70]. In this study, profitability was measured by ROA; sales growth was measured as the annual growth rate of firm sales; financial resources was measured by firm liquidity, computed as the ratio of cash flow to sales; financial leverage was measured as the ratio of debt to total assets; firm size was measured as the natural logarithm of sales; and finally, state-ownership was measured by a dummy variable, which was coded as 1 if the ultimate owner of a firm was the Chinese government and its agencies, and coded as 0 otherwise. In addition, we also controlled for other two variables that are conceptually associated with managerial mindfulness-TMT members' attention to past-moment events and their attention to future-moment events. We relied on the data of textual analyses noted above to measure these two variables. Specifically, attention to the past was computed as: attention to past $=\frac{\text { tpast }_{i, t}}{\text { tpast }_{i, t}+\text { tpresent }_{i, t}+\text { tfuture }_{i, t}}$, and attention to the future was computed as: attention to future $=\frac{t \text { future }_{i, t}}{\text { tpast }_{i, t}+\text { tpresen }_{i, t}+\text { tfuture } i, t}$.

Previous studies also show that corporate governance influences R\&D activities and we controlled for two variables of corporate governance. Board independence was measured as the ratio of the number of independent directors to the number of all directors of a board. CEO duality was measured by a dummy variable, coded as 1 if the CEO served as chairman of the board, and 0 otherwise.

We also controlled for two industry-level variables: market munificence and market dynamism. Following prior studies, we regressed the total sales of an industry to the year, and then obtained the regression coefficients [71]. Market munificence of an industry in a given year was measured as the corresponding regression coefficient divided by the industry average sales. Market dynamism of an industry in a given year was measured as the standard error of the corresponding regression coefficient divided by the industry average sales.

Correction for endogeneity-It is known that endogeneity is a serious problem to all similar studies. Measurement errors, omitted variables, and mutual causal relationships may all lead to endogenous problems. In this paper, omitted variables and mutual causal relationships are the main 
source of endogenous problems. First, managerial mindfulness studied in this paper is a relatively stable psychological feature, which is hardly affected by R\&D investment, so the possibility of reciprocal causation is very low. The source of endogeneity should be omitted variables. Second, some scholars use an instrumental variable approach to solve the problem of the omitted variables, but it is very difficult to find a good instrumental variable. Therefore, some scholars have adopted another method to control the endogenous problems caused by the omitted variables (Wooldridge, 2010). Following the latter approach, we controlled for endogeneity, or the possibility that TMT members are drawn to certain situations and/or that some conditions particularly allow them to demonstrate managerial mindfulness tendencies. To do this, we regressed our measure of managerial mindfulness against a set of antecedent variables. The antecedent variables, which captured key aspects of the TMT members' entry conditions, were measured in $t-1$ (the year prior to the TMT members' start). Among all these variables, only three significantly predicted managerial mindfulness. Specifically, financial resources were negatively related $(p<0.001)$, firm age and state ownership was positively related $(p<0.05 ; p<0.01)$ to our managerial mindfulness. The overall model was significant $\left(\mathbf{R}^{2}=0.0161\right.$; $p<0.001)$. Using the regression coefficients for the three significant variables, we calculated each predicted managerial mindfulness and included that value as an endogeneity control in our analyses.

\subsection{Estimation Methods}

Based upon Wooldridge (2010), we adopted the following procedures for data analyses. First, we used the Breusch-Pagan Lagrange multiplier test to decide, the panel data method was more appropriate. Second, for the panel data method, we needed to choose between fixed effect and random effect models. The independent variable of interest-managerial mindfulness-reflects TMT members' shared psychological state in which attention is paid to internal and external present-moment events. As a collective psychological state, we suspect that managerial mindfulness is relatively stable over time. Our data confirmed this point. In fact, our panel data set indicated that the variability of managerial mindfulness of a given firm within the studying period of time (i.e.; 2010-2014) was nearly zero. Therefore, a firm fixed-effects panel regression was not suitable to estimate the coefficient of managerial mindfulness-a time-invariant variable in our study. Finally, we used the modified Wald test to check for heteroscedasticity (Chi2 $=4.05 \mathrm{E}+5, p=0.000)$ and Wooldridge test for autocorrelation $(\mathrm{F}=71.589$, $p=0.000$ ) in our panel data set, and the results suggested that they were significant and we need to address them. We therefore clustered standard errors at the firm level to adjust for heteroscedasticity. Considering the above reasons, we implemented the Cragg model by following Wooldridge's (2010) recommendations. That is, we implemented a two-step regression approach. In the first step, we used Probit model to regress binary variable of R\&D decisions, and in the second step, we used a FGLS model to regress continuous variables of R\&D intensity. The FGLS panel method can estimate the coefficient of this time-invariant variable. Second, compared with the traditional random-effects model and Fama-MacBeth regression, the FGLS panel method can deal with autocorrelation which was present in our panel data set. In addition, the FGLS panel method can also account for the significant heteroscedasticity presented in our panel data set. Moreover, we used one-year lag between the dependent variable and other variables in order to avoid reverse causality.

\section{Results and Discussion}

\subsection{Descriptive Statistics and Correlation Analysis}

Tables 1 and 2 present the descriptive statistics and the correlations of the variables of this study. It seems that some variables were highly correlated with each other, suggesting the possibility of multi-collinearity problem. We used variance inflation factors (VIFs) to check for multi-collinearity and found that most of VIFs were less than 2, substantially below the rule-of-thumb cutoff of 10 except for ROA, financial leverage and past financial performance. The reason may be that the measurements of these variables were all based on same financial data. In order to avoid the possible harmful 
multi-collinearity, we mean-centered all of the independent variables, control variable and moderators. Furthermore, due to the high correlation between attention to future and attention to past, we entered them into regression analyses separately.

Table 1. Descriptive Statistics.

\begin{tabular}{|c|c|c|c|c|c|c|c|}
\hline & Mean & SD & Median & Min & Max & First Quartile & Third Quartile \\
\hline 1. Profitability & 0.0122 & 1.0182 & 0.0274 & -48.3159 & 4.8366 & 0.0067 & 0.0585 \\
\hline 2. Sales growth & 0.5876 & 14.2534 & 0.0913 & -28.4967 & 665.5401 & -0.0519 & 0.2352 \\
\hline 3. Financial resources & 0.0318 & 0.1336 & 0.0338 & -4.2696 & 0.5227 & -0.0047 & 0.0783 \\
\hline 4. Financial leverage & 0.5657 & 1.3738 & 0.5150 & 0.0000 & 63.9712 & 0.3744 & 0.6631 \\
\hline 5. Firm size & 9.3943 & 0.7004 & 9.3755 & 4.8001 & 11.7993 & 9.0350 & 9.8069 \\
\hline 6. State-ownership & 0.5547 & 0.4971 & 1 & 0 & 1 & 0 & 1 \\
\hline 7. CEO duality & 0.1417 & 0.3488 & 0 & 0 & 1 & 0 & 0 \\
\hline 8. Board independence & 0.3643 & 0.0515 & 0.3333 & 0.1818 & 0.6667 & 0.3333 & 0.3750 \\
\hline 9. Market munificence & -0.0184 & 0.1633 & -0.0002 & -4.6277 & 0.9123 & -0.0008 & -0.0001 \\
\hline 10. Market dynamism & 0.0128 & 0.1316 & 0.0000 & 0.0000 & 2.7845 & 0.0000 & 0.0003 \\
\hline 11. Attention to past & 0.2099 & 0.0891 & 0.2117 & 0.0000 & 0.4124 & 0.1417 & 0.2810 \\
\hline 12. Attention to future & 0.5771 & 0.1786 & 0.5732 & 0.0000 & 0.9785 & 0.4368 & 0.7122 \\
\hline 13. Firm age & 15.3618 & 4.2027 & 15 & 1 & 30 & 13 & 18 \\
\hline 14. Slack resource & 0.0078 & 0.1000 & 0.0028 & -1.2685 & 0.7202 & -0.0282 & 0.0376 \\
\hline $\begin{array}{l}\text { 15. Past financial } \\
\text { performance }\end{array}$ & 0.0286 & 0.3715 & 0.0287 & -16.2940 & 4.4884 & 0.0055 & 0.0594 \\
\hline 16. Endogeneity control & 0.06 & 0.03 & 0.07 & -0.28 & 0.23 & 0.05 & 0.08 \\
\hline $\begin{array}{l}\text { 17. Managerial } \\
\text { mindfulness }\end{array}$ & 0.35 & 0.18 & 0.33 & 0.00 & 1.00 & 0.22 & 0.48 \\
\hline 18. R\&D Decision & 0.8622 & 0.3448 & 1 & 0 & 1 & 1 & 1 \\
\hline 19. R\&D Intensity (\%) & 1.36 & 1.34 & 1.06 & 0.00 & 6.86 & 0.18 & 2.16 \\
\hline
\end{tabular}


Table 2. Correlations.

\begin{tabular}{|c|c|c|c|c|c|c|c|c|c|c|c|c|c|c|c|c|c|c|c|}
\hline & 1 & 2 & 3 & 4 & 5 & 6 & 7 & 8 & 9 & 10 & 11 & 12 & 13 & 14 & 15 & 16 & 17 & 18 & 19 \\
\hline 1. Profitability & 1 & & & & & & & & & & & & & & & & & & \\
\hline 2.Sales growth & 0.002 & 1 & & & & & & & & & & & & & & & & & \\
\hline 3. Financial resources & -0.030 & -0.007 & 1 & & & & & & & & & & & & & & & & \\
\hline 4.Financial leverage & $-\underset{* *}{-0.952}$ & 0.003 & -0.036 & 1 & & & & & & & & & & & & & & & \\
\hline 5.Firm size & $\underset{* *}{0.059}$ & 0.017 & 0.218 & -0.074 & 1 & & & & & & & & & & & & & & \\
\hline 6. State-ownership & 0.017 & 0.006 & -0.014 & -0.016 & $\underset{* *}{0.230}$ & 1 & & & & & & & & & & & & & \\
\hline 7.CEO duality & 0.008 & -0.004 & 0.013 & -0.013 & 0.008 & -0.009 & 1 & & & & & & & & & & & & \\
\hline 8. Board independence & -0.013 & 0.006 & $\underset{*}{-0.041}$ & 0.009 & -0.030 & 0.019 & 0.023 & 1 & & & & & & & & & & & \\
\hline 9.Market munificence & -0.004 & 0.003 & -0.014 & 0.011 & $\underset{* *}{0.061}$ & $\underset{* *}{0.069}$ & -0.013 & 0.011 & 1 & & & & & & & & & & \\
\hline 10.Market dynamism & 0.001 & -0.004 & $\underset{*}{-0.053}$ & -0.009 & -0.093 & $-\underset{*}{-0.053}$ & 0.020 & -0.013 & -0.373 & 1 & & & & & & & & & \\
\hline 11.Attention to past & $\underset{*}{0.050}$ & 0.005 & 0.107 & -0.057 & 0.414 & $\underset{* *}{0.264}$ & -0.012 & -0.113 & 0.016 & -0.017 & 1 & & & & & & & & \\
\hline 12.Attention to future & $\underset{*}{-0.050}$ & -0.008 & -0.104 & $\underset{* *}{0.057}$ & -0.414 & -0.262 & 0.010 & $\underset{* *}{0.141}$ & -0.011 & 0.015 & -0.966 & 1 & & & & & & & \\
\hline 13.Firm age & -0.006 & $\underset{*}{0.052}$ & -0.033 & 0.022 & -0.111 & -0.003 & $\underset{* *}{0.073}$ & -0.058 & 0.009 & -0.004 & $\underset{* *}{-0.254}$ & $\underset{* *}{0.245}$ & 1 & & & & & & \\
\hline 14.Slack resource & $\underset{*}{0.047}$ & 0.025 & $\underset{* *}{0.142}$ & -0.020 & $\underset{* *}{0.063}$ & -0.023 & 0.014 & 0.010 & -0.001 & 0.009 & 0.034 & -0.032 & $\underset{*}{-0.044}$ & 1 & & & & & \\
\hline $\begin{array}{l}\text { 15. Past financial } \\
\text { performance }\end{array}$ & $\underset{* *}{0.929}$ & -0.002 & $\underset{*}{-0.047}$ & $\underset{* *}{-0.881}$ & 0.028 & -0.007 & 0.010 & 0.000 & -0.007 & -0.001 & $0.045^{*}$ & $\underset{*}{-0.045}$ & -0.007 & -0.024 & 1 & & & & \\
\hline 16.Endogeneity control & -0.007 & 0.041 & -0.064 & 0.032 & $\underset{* *}{0.067}$ & $\underset{* *}{0.355}$ & $\underset{* *}{0.098}$ & 0.001 & 0.041 & $\underset{*}{-0.042}$ & -0.021 & 0.018 & 0.589 & -0.056 & -0.002 & 1 & & & \\
\hline $\begin{array}{l}\text { 17.Managerial } \\
\text { mindfulness }\end{array}$ & -0.018 & 0.029 & -0.030 & 0.016 & 0.010 & $\underset{* *}{0.068}$ & 0.022 & 0.016 & $\underset{*}{0.042}$ & -0.012 & -0.018 & 0.034 & 0.013 & -0.063 & 0.011 & $\underset{* *}{0.121}$ & 1 & & \\
\hline 18.R\&D Decision & -0.008 & -0.005 & $\underset{* *}{0.117}$ & -0.039 & 0.340 & $\underset{* *}{0.097}$ & 0.005 & -0.027 & 0.021 & -0.067 & 0.152 & -0.150 & -0.093 & 0.001 & -0.018 & $\underset{* *}{0.079}$ & $\underset{* *}{0.077}$ & 1 & \\
\hline 19.R\&D Intensity (\%) & 0.030 & -0.025 & $\underset{* *}{0.117}$ & $\underset{* *}{-0.060}$ & $\underset{* *}{0.191}$ & 0.019 & 0.013 & -0.015 & 0.019 & $\underset{*}{-0.048}$ & $\underset{* *}{0.075}$ & $\underset{* *}{-0.080}$ & $\underset{* *}{-0.077}$ & 0.033 & $\underset{*}{0.041}$ & 0.039 & $\underset{* *}{0.045}$ & $\underset{* *}{0.404}$ & 1 \\
\hline
\end{tabular}




\subsection{Empirical Results}

Model 1-4 in Table 3 presents the results of the first-stage model, which was a probit regression of the choice of conducting an R\&D activity or not against the factors thought to predict whether a firm will engage in R\&D activity. The dependent variable was the dummy variable, indicating whether a firm will engage in R\&D activity. Model 1 and Model 3, the baseline model, included an intercept term and the measures of firm-level and regional level variables. Model 2 and Model 4 added the independent variable as the main factor expected to affect corporate R\&D behavior. As anticipated, Model 2 and Model 4 reports that managerial mindfulness and R\&D intensity is positively associated $(b=0.919, p<0.1)$. Similarly, Model 5 indicates a positive association between managerial mindfulness and $R \& D$ intensity $(b=0.913, p<0.1)$. Therefore, we can conclude that Hypothesis 1 is supported.

Table 3. Empirical Results of Probit Regression.

\begin{tabular}{|c|c|c|c|c|}
\hline & RD & RD & RD & RD \\
\hline Constant & $\begin{array}{c}-8.871^{* * *} \\
(-3.38)\end{array}$ & $\begin{array}{c}-8.986 * * * \\
(-3.52)\end{array}$ & $\begin{array}{c}-8.702 * * \\
(-3.15)\end{array}$ & $\begin{array}{c}-8.792 * * \\
(-3.26)\end{array}$ \\
\hline Profitability & $\begin{array}{c}-2.148^{* *} \\
(-3.18)\end{array}$ & $\begin{array}{c}-2.095^{* *} \\
(-3.17)\end{array}$ & $\begin{array}{c}-2.138^{* *} \\
(-3.17)\end{array}$ & $\begin{array}{c}-2.085^{* *} \\
(-3.16)\end{array}$ \\
\hline Sales growth & $\begin{array}{c}-0.00584 \\
(-0.82)\end{array}$ & $\begin{array}{c}-0.00585 \\
(-0.79)\end{array}$ & $\begin{array}{c}-0.00585 \\
(-0.83)\end{array}$ & $\begin{array}{c}-0.00587 \\
(-0.80)\end{array}$ \\
\hline Financial resources & $\begin{array}{l}2.011 \\
(1.95)\end{array}$ & $\begin{array}{l}2.004 \text { * } \\
(1.96)\end{array}$ & $\begin{array}{l}2.014 \\
(1.95)\end{array}$ & $\begin{array}{c}2.007 * \\
(1.97)\end{array}$ \\
\hline Financial leverage & $\begin{array}{c}-2.007^{* * * *} \\
(-3.89)\end{array}$ & $\begin{array}{c}-1.982 * * * \\
(-3.93)\end{array}$ & $\begin{array}{c}-2.003^{* * *} \\
(-3.88)\end{array}$ & $\begin{array}{c}-1.978^{* * *} \\
(-3.92)\end{array}$ \\
\hline Firm size & $\begin{array}{c}1.487^{* * *} \\
(5.62)\end{array}$ & $\begin{array}{c}1.475^{* * *} \\
(5.74)\end{array}$ & $\begin{array}{c}1.463^{* * *} \\
(5.53)\end{array}$ & $\begin{array}{c}1.444^{* * *} \\
(5.62)\end{array}$ \\
\hline State-ownership & $\begin{array}{l}-0.264 \\
(-0.78)\end{array}$ & $\begin{array}{l}-0.260 \\
(-0.79)\end{array}$ & $\begin{array}{l}-0.284 \\
(-0.84)\end{array}$ & $\begin{array}{l}-0.285 \\
(-0.87)\end{array}$ \\
\hline CEO duality & $\begin{array}{c}-0.0330 \\
(-0.14)\end{array}$ & $\begin{array}{l}-0.0523 \\
(-0.23)\end{array}$ & $\begin{array}{c}-0.0351 \\
(-0.15)\end{array}$ & $\begin{array}{c}-0.0548 \\
(-0.24)\end{array}$ \\
\hline Board independent & $\begin{array}{l}-0.213 \\
(-0.09)\end{array}$ & $\begin{array}{l}-0.353 \\
(-0.16)\end{array}$ & $\begin{array}{l}-0.0597 \\
(-0.03)\end{array}$ & $\begin{array}{l}-0.156 \\
(-0.07)\end{array}$ \\
\hline Market munificence & $\begin{array}{l}0.251 \\
(0.47)\end{array}$ & $\begin{array}{l}0.211 \\
(0.42)\end{array}$ & $\begin{array}{l}0.252 \\
(0.47)\end{array}$ & $\begin{array}{l}0.212 \\
(0.42)\end{array}$ \\
\hline Market dynamism & $\begin{array}{l}-1.121 \\
(-1.66)\end{array}$ & $\begin{array}{l}-1.100 \\
(-1.72)\end{array}$ & $\begin{array}{l}-1.119 \\
(-1.65)\end{array}$ & $\begin{array}{l}-1.098 \\
(-1.72)\end{array}$ \\
\hline Attention to past & $\begin{array}{l}-0.314 \\
(-0.18)\end{array}$ & $\begin{array}{l}-0.446 \\
(-0.26)\end{array}$ & & \\
\hline Attention to future & & & $\begin{array}{l}-0.157 \\
(-0.18)\end{array}$ & $\begin{array}{l}-0.178 \\
(-0.20)\end{array}$ \\
\hline Firm age & $\begin{array}{c}-0.0977 * \\
(-2.31)\end{array}$ & $\begin{array}{c}-0.105^{*} \\
(-2.51)\end{array}$ & $\begin{array}{c}-0.0951 \text { * } \\
(-2.26)\end{array}$ & $\begin{array}{c}-0.101 \text { * } \\
(-2.44)\end{array}$ \\
\hline Slack resources & $\begin{array}{c}-1.555^{*} \\
(-1.98)\end{array}$ & $\begin{array}{l}-1.514 \\
(-1.95)\end{array}$ & $\begin{array}{l}-1.572 * \\
(-2.00)\end{array}$ & $\begin{array}{l}-1.534 \\
(-1.98)\end{array}$ \\
\hline Past financial performance & $\begin{array}{l}-1.631 \\
(-1.19)\end{array}$ & $\begin{array}{l}-1.692 \\
(-1.28)\end{array}$ & $\begin{array}{l}-1.645 \\
(-1.21)\end{array}$ & $\begin{array}{l}-1.709 \\
(-1.29)\end{array}$ \\
\hline Endogeneity control & $\begin{array}{c}32.53^{* * *} \\
(8.40)\end{array}$ & $\begin{array}{c}30.64^{* * *} \\
(8.11)\end{array}$ & $\begin{array}{c}32.52 * * * \\
(8.40)\end{array}$ & $\begin{array}{c}30.63^{* * *} \\
(8.11)\end{array}$ \\
\hline Managerial mindfulness & & $\begin{array}{c}0.919^{+} \\
(1.92)\end{array}$ & & $\begin{array}{c}0.914^{+} \\
(1.91)\end{array}$ \\
\hline $\begin{array}{c}\text { lnsig2u } \\
\text { Constant }\end{array}$ & $\begin{array}{c}2.465^{* * *} \\
(15.60)\end{array}$ & $\begin{array}{c}2.353^{* * *} \\
(14.68)\end{array}$ & $\begin{array}{c}2.466^{* * *} \\
(15.60)\end{array}$ & $\begin{array}{c}2.354^{* * *} \\
(14.67)\end{array}$ \\
\hline Wald Chi & $129.95^{* * *}$ & $130.9^{* * *}$ & $129.67^{* * *}$ & $130.46^{* * *}$ \\
\hline
\end{tabular}

Table 4 shows the results of the FGLS panel regression. Model 1-3 presents the empirical results when attention to past be used as a control variable, and Model 4-6 reports the empirical results when attention to future is used as a control variable. Model 1 and Model 4 include only control variables. 
Table 4. Empirical Results of FGLS Estimation.

\begin{tabular}{|c|c|c|c|c|c|c|}
\hline & RDI (\%) & RDI (\%) & RDI (\%) & RDI (\%) & RDI (\%) & RDI (\%) \\
\hline Constant & $\begin{array}{c}-0.949^{* *} \\
(-3.27)\end{array}$ & $\begin{array}{c}-1.045^{* * *} \\
(-3.58)\end{array}$ & $\begin{array}{c}-0.906^{* *} \\
(-3.21)\end{array}$ & $\begin{array}{c}-1.166^{* * *} \\
(-3.70)\end{array}$ & $\begin{array}{c}-1.240^{* * *} \\
(-3.92)\end{array}$ & $\begin{array}{c}-1.200 * * * \\
(-3.95)\end{array}$ \\
\hline Profitability & $\begin{array}{c}-0.0801 \\
(-1.33)\end{array}$ & $\begin{array}{c}-0.0871 \\
(-1.40)\end{array}$ & $\begin{array}{c}-0.169^{* *} \\
(-2.73)\end{array}$ & $\begin{array}{c}-0.0781 \\
(-1.28)\end{array}$ & $\begin{array}{c}-0.0841 \\
(-1.35)\end{array}$ & $\begin{array}{l}-0.158^{*} \\
(-2.53)\end{array}$ \\
\hline Sales growth & $\begin{array}{c}-0.000807 \\
(-1.46)\end{array}$ & $\begin{array}{c}-0.000867 \\
(-1.55)\end{array}$ & $\begin{array}{c}-0.000906 \\
(-1.64)\end{array}$ & $\begin{array}{c}-0.000850 \\
(-1.50)\end{array}$ & $\begin{array}{c}-0.000890 \\
(-1.56)\end{array}$ & $\begin{array}{c}-0.000918 \\
(-1.64)\end{array}$ \\
\hline Financial resources & $\begin{array}{c}0.00768 \\
(0.09)\end{array}$ & $\begin{array}{c}0.00506 \\
(0.06)\end{array}$ & $\begin{array}{c}0.0909 \\
(1.07)\end{array}$ & $\begin{array}{c}0.00511 \\
(0.06)\end{array}$ & $\begin{array}{c}0.00236 \\
(0.03)\end{array}$ & $\begin{array}{c}0.0833 \\
(0.95)\end{array}$ \\
\hline Financial leverage & $\begin{array}{c}-0.0723 \\
(-1.92)\end{array}$ & $\begin{array}{c}-0.0755 \\
(-1.94)\end{array}$ & $\begin{array}{c}-0.0526 \\
(-1.40)\end{array}$ & $\begin{array}{c}-0.0644 \\
(-1.68)\end{array}$ & $\begin{array}{c}-0.0691 \\
(-1.76)\end{array}$ & $\begin{array}{c}-0.0385 \\
(-1.02)\end{array}$ \\
\hline Firm size & $\begin{array}{c}0.291 * * * \\
(9.89)\end{array}$ & $\begin{array}{c}0.306^{* * *} \\
(10.44)\end{array}$ & $\begin{array}{c}0.290^{* * * *} \\
(10.42)\end{array}$ & $\begin{array}{c}0.293^{* * *} \\
(9.56)\end{array}$ & $\begin{array}{c}0.302 * * * \\
(9.95)\end{array}$ & $\begin{array}{c}0.298^{* * *} \\
(10.09)\end{array}$ \\
\hline State-ownership & $\begin{array}{c}-0.196^{* * *} \\
(-4.13)\end{array}$ & $\begin{array}{c}-0.197^{* * *} \\
(-4.23)\end{array}$ & $\begin{array}{c}-0.209^{* * * *} \\
(-4.73)\end{array}$ & $\begin{array}{c}-0.179^{* * *} \\
(-3.70)\end{array}$ & $\begin{array}{c}-0.190^{* * *} \\
(-4.01)\end{array}$ & $\begin{array}{c}-0.190^{* * *} \\
(-4.13)\end{array}$ \\
\hline CEO duality & $\begin{array}{c}0.0323 \\
(1.66)\end{array}$ & $\begin{array}{l}0.0295 \\
(1.44)\end{array}$ & $\begin{array}{c}0.0427^{*} \\
(2.29)\end{array}$ & $\begin{array}{c}0.0223 \\
(1.06)\end{array}$ & $\begin{array}{l}0.0223 \\
(1.03)\end{array}$ & $\begin{array}{c}0.0270 \\
(1.27)\end{array}$ \\
\hline Board independent & $\begin{array}{c}-0.576 \text { * } \\
(-2.32)\end{array}$ & $\begin{array}{c}-0.611 \text { * } \\
(-2.44)\end{array}$ & $\begin{array}{c}-0.609 * \\
(-2.42)\end{array}$ & $\begin{array}{l}-0.465 \\
(-1.82)\end{array}$ & $\begin{array}{l}-0.501 \\
(-1.95)\end{array}$ & $\begin{array}{c}-0.528 \text { * } \\
(-2.05)\end{array}$ \\
\hline Market munificence & $\begin{array}{c}-0.0778 \\
(-0.88)\end{array}$ & $\begin{array}{c}-0.0793 \\
(-0.88)\end{array}$ & $\begin{array}{c}-0.0649 \\
(-0.71)\end{array}$ & $\begin{array}{c}-0.0816 \\
(-0.92)\end{array}$ & $\begin{array}{c}-0.0840 \\
(-0.93)\end{array}$ & $\begin{array}{c}-0.0756 \\
(-0.83)\end{array}$ \\
\hline Market dynamism & $\begin{array}{c}-0.000999 \\
(-0.01)\end{array}$ & $\begin{array}{c}-0.0122 \\
(-0.12)\end{array}$ & $\begin{array}{c}-0.0214 \\
(-0.21)\end{array}$ & $\begin{array}{c}-0.00850 \\
(-0.08)\end{array}$ & $\begin{array}{c}-0.0183 \\
(-0.18)\end{array}$ & $\begin{array}{c}-0.0182 \\
(-0.18)\end{array}$ \\
\hline Attention to past & $\begin{array}{l}-0.405 \\
(-1.87)\end{array}$ & $\begin{array}{c}-0.507^{*} \\
(-2.30)\end{array}$ & $\begin{array}{l}-0.366 \\
(-1.81)\end{array}$ & & & \\
\hline Attention to future & & & & $\begin{array}{l}0.0588 \\
(0.49)\end{array}$ & $\begin{array}{c}0.0861 \\
(0.71)\end{array}$ & $\begin{array}{c}0.0953 \\
(0.82)\end{array}$ \\
\hline Firm age & $\begin{array}{c}-0.0440 * * * \\
(-7.85)\end{array}$ & $\begin{array}{c}-0.0462 * * * \\
(-8.37)\end{array}$ & $\begin{array}{c}-0.0480 * * * \\
(-8.87)\end{array}$ & $\begin{array}{c}-0.0420 * * * \\
(-7.42)\end{array}$ & $\begin{array}{c}-0.0442^{* * *} \\
(-7.94)\end{array}$ & $\begin{array}{c}-0.0454 * * * \\
(-8.25)\end{array}$ \\
\hline Slack resources & $\begin{array}{l}0.128 \\
(1.52)\end{array}$ & $\begin{array}{l}0.132 \\
(1.50)\end{array}$ & $\begin{array}{l}0.178^{*} \\
(2.11)\end{array}$ & $\begin{array}{l}0.128 \\
(1.44)\end{array}$ & $\begin{array}{l}0.131 \\
(1.44)\end{array}$ & $\begin{array}{l}0.180 * \\
(1.99)\end{array}$ \\
\hline Past financial performance & $\begin{array}{c}0.0636 \\
(0.53)\end{array}$ & $\begin{array}{c}0.0692 \\
(0.57)\end{array}$ & $\begin{array}{c}0.580^{* * * *} \\
(3.78)\end{array}$ & $\begin{array}{l}0.0866 \\
(0.73)\end{array}$ & $\begin{array}{c}0.0841 \\
(0.70)\end{array}$ & $\begin{array}{c}0.605^{* * *} \\
(3.89)\end{array}$ \\
\hline Endogeneity control & $\begin{array}{c}6.264^{* * *} \\
(14.74)\end{array}$ & $\begin{array}{c}6.236^{* * *} \\
(14.46)\end{array}$ & $\begin{array}{c}6.271^{* * * *} \\
(14.15)\end{array}$ & $\begin{array}{c}6.157^{* * *} \\
(14.24)\end{array}$ & $\begin{array}{c}6.154^{* * *} \\
(14.10)\end{array}$ & $\begin{array}{c}6.174^{* * *} \\
(13.84)\end{array}$ \\
\hline \multicolumn{2}{|c|}{ Managerial mindfulness } & $\begin{array}{c}0.100^{+} \\
(1.87)\end{array}$ & $\begin{array}{c}0.113 \text { * } \\
(2.07)\end{array}$ & & $\begin{array}{c}0.0971^{+} \\
(1.80)\end{array}$ & $\begin{array}{c}0.108^{*} \\
(1.98)\end{array}$ \\
\hline \multicolumn{3}{|c|}{ Managerial mindfulness $X$ firm age } & $\begin{array}{c}-0.0248 * \\
(-1.92)\end{array}$ & & & $\begin{array}{c}-0.0239 * \\
(-1.85)\end{array}$ \\
\hline \multicolumn{3}{|c|}{ Managerial mindfulness $X$ slack resources } & $\begin{array}{c}0.965^{*} \\
(1.84)\end{array}$ & & & $\begin{array}{l}0.947^{*} \\
(1.78)\end{array}$ \\
\hline Managerial mindfulness & ast financial & formance & $\begin{array}{c}-1.183^{* * * *} \\
(-4.09)\end{array}$ & & & $\begin{array}{c}-1.213^{* * *} \\
(-4.16)\end{array}$ \\
\hline Wald Chi & $375.52 * * *$ & $388.07^{* * *}$ & $403.88^{* * *}$ & $366.37^{* * *}$ & $379.11^{* * *}$ & $392.53 * * *$ \\
\hline
\end{tabular}

Hypothesis 1 suggests a positive relationship between managerial mindfulness and R\&D intensity. We test Hypothesis 1 by Model 2 and Model 5. Model 2 reports that managerial mindfulness and R\&D intensity is positively associated $(b=0.1, p<0.1)$. Similarly, Model 5 indicates a positive association between managerial mindfulness and $R \& D$ intensity $(b=0.0971, p<0.1)$. Therefore, we can conclude that Hypothesis 1 is supported.

We then test the moderating effect of firm age, slack resource, and past financial performance (Hypotheses 2-4). Model 3 and Model 6 report the empirical results. Hypothesis 2 predicts that firm age negatively moderates the positive relationship between managerial mindfulness and R\&D intensity. According to Model 3, the interaction term between managerial mindfulness and firm age is negative and significant $(b=-0.0248, p<0.05)$, thereby supporting Hypothesis 2 . Similarly, Model 6 also supports Hypothesis 2 by showing a negative interaction term between managerial mindfulness and firm age $(b=-0.0239, p<0.05)$.

Hypothesis 3 predicts a positive moderating effect of slack resource on the relationship between R\&D intensity and managerial mindfulness. According to Model 3, the interaction term between managerial mindfulness and slack resources is positive and significant $(b=0.965, p<0.05)$, thereby supporting Hypothesis 3. Similarly, Model 6 also supports Hypothesis 3 by showing a positive interaction term between managerial mindfulness and slack resources $(b=0.947, p<0.05)$. 
Hypothesis 4 predicts a negative moderating effect of past financial performance on the relationship between R\&D intensity and managerial mindfulness. According to Model 3, the interaction term between managerial mindfulness and past financial performance is negative and significant $(b=-1.183$, $p<0.001$ ), thereby supporting Hypothesis 4. Similarly, Model 6 also supports Hypothesis 4 by showing a negative interaction term between managerial mindfulness and past financial performance $(\mathrm{b}=-1.213, p<0.001)$.

To better illustrate the moderating effects, we used Aiken and West's approach (1991) to plotting the interaction effects of the three moderating variables (Figures 1-3) [72]. The estimated coefficients in Model 3 in Table 3 were used to plot these figures. Figure 1 illustrates the significant moderating effect of firm age. As managerial mindfulness increases from one standard deviation below the mean to one standard deviation above the mean, R\&D intensity increases from 1.20429 to 1.28326 for younger firms ( $\Delta=0.079)$; in contrast, for older firms, the R\&D intensity increases from 0.83873 to $0.84192(\Delta=0.003)$.

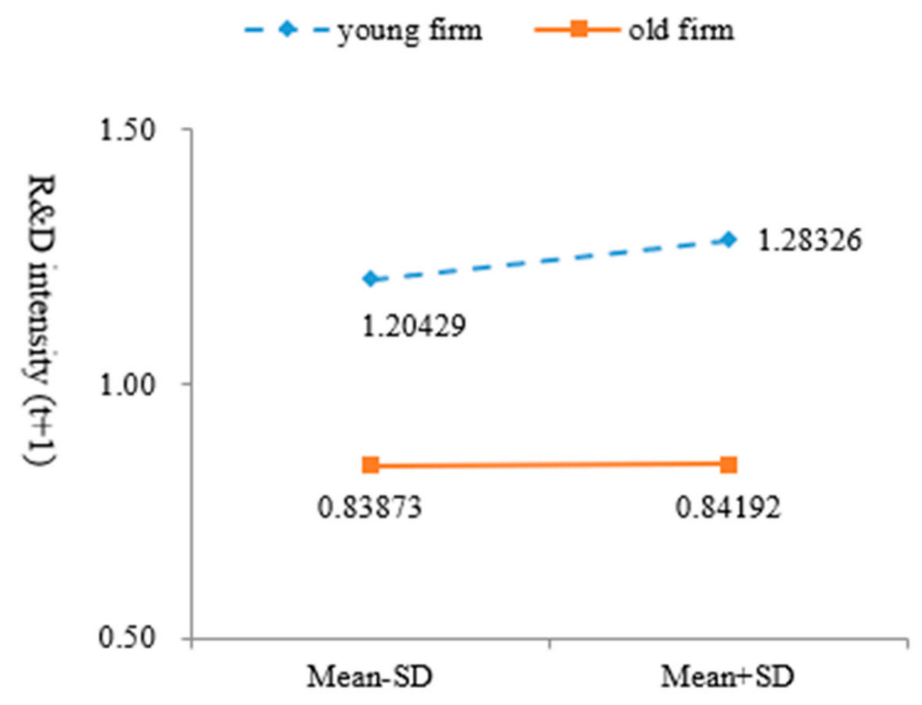

Managerial mindfulness

Figure 1. Moderating effect of firm age. 


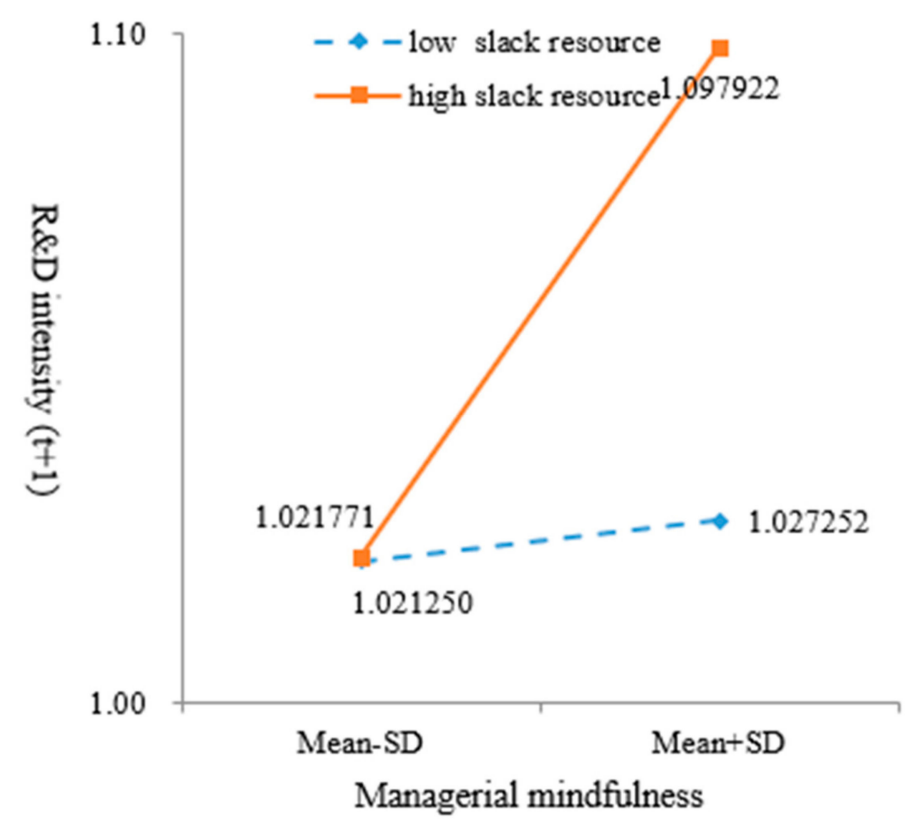

Figure 2. Moderating effect of slack resource.

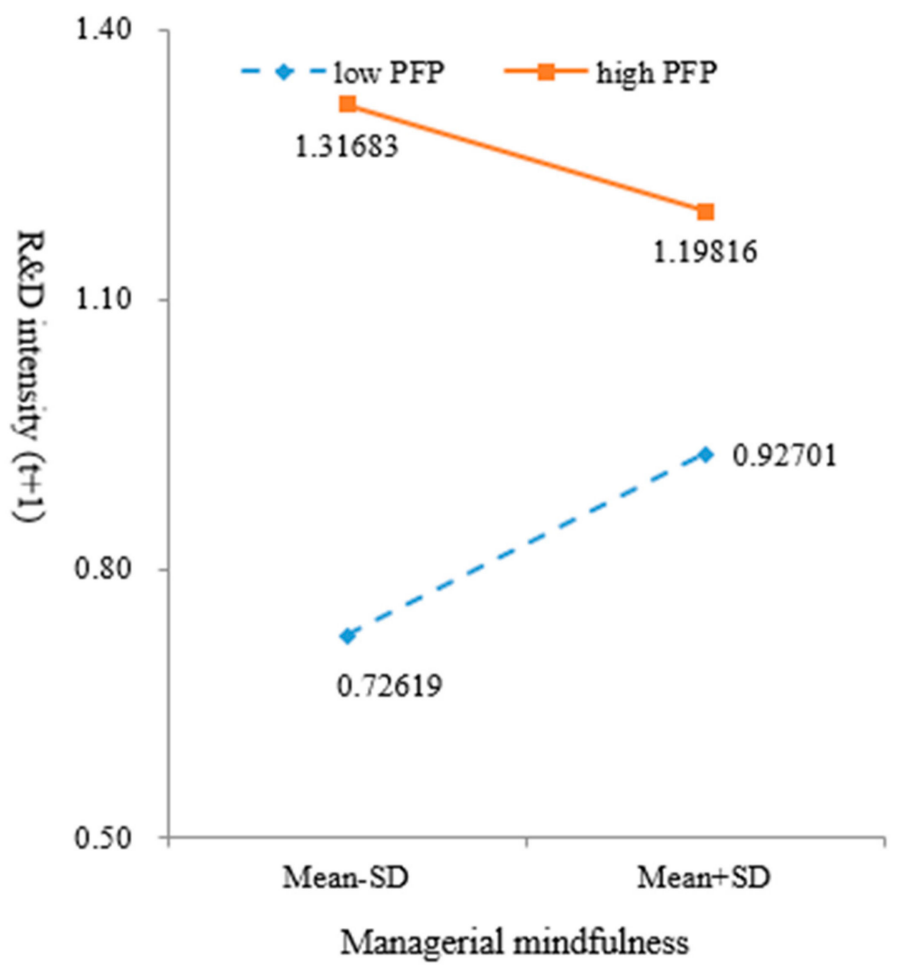

Figure 3. Moderating effect of past financial performance.

Figure 2 illustrates the significant moderating effect of slack resource. As managerial mindfulness increases from one standard deviation below the mean to one standard deviation above the mean, the R\&D intensity increases from 1.021771 to 1.097922 for firms with lower level of slack resources $(\Delta=0.076)$; in contrast, for firms with higher level of slack resources, the R\&D intensity increases from 1.021250 to $1.027252(\Delta=0.006)$.

Figure 3 illustrates the significant moderating effect of past financial performance. As managerial mindfulness increases from one standard deviation below the mean to one standard deviation above the mean, the R\&D intensity increases from 0.72619 to 0.92701 for firms with lower past financial performance $(\Delta=0.201)$; in contrast, for firms with higher past financial performance, the $R \& D$ 
intensity decreases from 1.31683 to $1.19816(\Delta=0.119)$. Since this paper selects the manufacturing enterprises listed in Shanghai in 2010-2014, it only controls the year effect and analyzes it with the time fixed effect model.

\subsection{Robust Test}

In this study, there are 320 observations' $R \& D=0$ among 2322 observations, which means that $13.78 \%$ of observations $R \& D=0$. Although the proportion is very small, considering that dependent variables are constrained by certain constraints, we conduct a robustness test with Tobit regression. The results of the empirical analysis are basically consistent with the above, and the reliability of the research conclusions is proved. The robustness test is shown in Table 5.

Table 5. Robust Results of Tobit Estimation.

\begin{tabular}{|c|c|c|}
\hline Constant & $\begin{array}{c}-7.46^{* * *} \\
(-8.63)\end{array}$ & $\begin{array}{c}-7.52 * * * \\
(-8.72)\end{array}$ \\
\hline Profitability & $\begin{array}{c}-0.513^{* *} \\
(-2.92)\end{array}$ & $\begin{array}{c}-0.487^{* *} \\
(-2.79)\end{array}$ \\
\hline Sales growth & $\begin{array}{c}-0.00114 \\
(-0.94)\end{array}$ & $\begin{array}{c}-0.00124 \\
(-1.02)\end{array}$ \\
\hline Financial resources & $\begin{array}{c}0.988 * * * \\
(-3.61)\end{array}$ & $\begin{array}{c}0.965^{* * *} \\
(-3.53)\end{array}$ \\
\hline Financial leverage & $\begin{array}{l}-0.255^{*} \\
(-2.24)\end{array}$ & $\begin{array}{c}-0.243 \text { * } \\
(-2.14)\end{array}$ \\
\hline Firm size & $\begin{array}{c}0.621^{* * *} \\
(-7.69)\end{array}$ & $\begin{array}{c}0.619^{* * *} \\
(-7.7)\end{array}$ \\
\hline State-ownership & $\begin{array}{c}-0.0192 \\
(-0.14)\end{array}$ & $\begin{array}{c}-0.0265 \\
(-0.19)\end{array}$ \\
\hline CEO duality & $\begin{array}{l}-0.0161 \\
(-0.32)\end{array}$ & $\begin{array}{c}-0.0183 \\
(-0.36)\end{array}$ \\
\hline Board independence & $\begin{array}{l}-0.641 \\
(-1.15)\end{array}$ & $\begin{array}{l}-0.626 \\
(-1.12)\end{array}$ \\
\hline Market munificence & $\begin{array}{l}-0.111 \\
(-0.81)\end{array}$ & $\begin{array}{l}-0.119 \\
(-0.86)\end{array}$ \\
\hline Market dynamism & $\begin{array}{c}0.141 \\
(-0.75)\end{array}$ & $\begin{array}{c}0.123 \\
(-0.66)\end{array}$ \\
\hline Attention to past & $\begin{array}{l}3.31^{* * *} \\
(-4.85)\end{array}$ & $\begin{array}{l}3.42 * * * \\
(-5.03)\end{array}$ \\
\hline Attention to future & $\begin{array}{l}2.26^{* * *} \\
(-9.64)\end{array}$ & $\begin{array}{l}2.31 * * * \\
(-9.85)\end{array}$ \\
\hline Firm age & $\begin{array}{c}0.0793^{* * *} \\
(-7.55)\end{array}$ & $\begin{array}{c}0.0731 \text { *** } \\
(-6.84)\end{array}$ \\
\hline Slack resource & $\begin{array}{l}-0.164 \\
(-0.86)\end{array}$ & $\begin{array}{l}-0.131 \\
(-0.69)\end{array}$ \\
\hline Managerial mindfulness & $\begin{array}{l}0.563 \text { * } \\
(-2.05)\end{array}$ & $\begin{array}{l}0.531^{+} \\
(-1.95)\end{array}$ \\
\hline sigma_u & $\begin{array}{l}1.42^{* * *} \\
(25.67)\end{array}$ & $\begin{array}{l}1.41^{* * *} \\
(25.71)\end{array}$ \\
\hline sigma_e & $\begin{array}{c}0.718^{* * *} \\
(55.20)\end{array}$ & $\begin{array}{c}0.719^{* * *} \\
(55.22)\end{array}$ \\
\hline Wald Chi & $256.78^{* * *}$ & $262.63^{* * *}$ \\
\hline
\end{tabular}

Note: ${ }^{+} p<0.1,{ }^{*} p<0.05,{ }^{* *} p<0.01,{ }^{* * *} p<0.001$; t statistics in parentheses.

\section{Conclusions}

In this study, we attempt to investigate the influence of managerial mindfulness on firm strategy and decision-making. We conceptualize managerial mindfulness as a collective psychological state shared by TMT members. Our conceptualization of managerial mindfulness differs from previous studies in two aspects. First, we view managerial mindfulness as a collective-level/team-level construct rather than an individual-level construct in most previous studies of mindfulness (Good et al.; 2016). 
Second, we emphasize that managerial mindfulness represents TMT members' collective attention to present-moment events and experiences, which differs from Weick et al.'s (1999) conceptualization of mindful organizing [31].

This paper has several theoretical implications. First, although many scholars have participated in the study of firm innovation, only recently have a few studies started to examine the firm innovation from the psychology perspective. Therefore, this is one of the few studies to explore firm innovation from the subjective characteristics of executive with an emphasis on the moderating effect of firm characteristics. Our study responds to Di Fabio's call for more research on the innovative contribution that psychology can make to the theme of sustainability and sustainable development [73]. In this paper, we focus on firm innovation from a psychology perspective and contribute to this emerging literature by finding that managerial mindfulness can drive $R \& D$ investment. This is also an important supplement to the literature on upper echelons theory. Managerial mindfulness can influence a company's strategic decisions and different concerns can produce different results. Second, the measurement of managerial mindfulness has always been a problem. This article cleverly combines psychology with management by using a psycholinguistic tools-content analysis of the part of board discussion and analysis of corporate annual reports [22,74], while other studies used surveys to do so [27]. This is an important complement to current research on managerial mindfulness and provides a reliable method for measuring managerial mindfulness. Finally, we also emphasize the moderating effect of firm characteristics, adding new insights to the existing studies on the relationship between managerial discretion and innovation. Meanwhile, this paper also contributes to the practice. The positive relationship between managerial mindfulness and $R \& D$ investment can provide reference for the government and top managers. Governments and top managers of enterprises can consciously cultivate CEOs' mindful thinking, so that managers can make more correct decisions that can bring a lot of innovation output to enterprises. Secondly, in the context of China's transition economy, enterprises should strive to improve the expectations of stakeholders so as to maintain a positive and optimistic attitude towards enterprises to further promote the decision-making of managers concerned about the emergence of innovative achievements.

Of course, there are still some limitations existing in this study. Even though we use a longitudinal data set, control for a set of firm-level variables, and employ one year of lag in managerial mindfulness and R\&D intensity. Moreover, the insufficient sample size and the limited sample source will affect the universality of the research conclusion to some extent. The following study can further expand the sample to improve the universality of the research. Secondly, for the measurement of managerial mindfulness, future research can adopt qualitative, quantitative, or mixed research methods according to the needs of research issues. In addition, it will be very interesting to compare comparably innovative companies with general companies to assess the impact of managers' awareness on innovation in the future. Finally, our research findings are based on an empirical analysis of Chinese listed companies, so we must exercise caution in extrapolating these results to other contexts. Specifically, our theory development is based on two psychological mechanisms of mindfulness, e.g.; self-regulation and goal-pursuit. Therefore, it is important to assess the generalizability of our research when the two psychological mechanisms of mindfulness are not met.

Drawing from two psychological mechanisms of mindfulness, e.g.; self-regulation and goal-pursuit, we propose that managerial mindfulness can positively affect R\&D intensity-a proxy for firm innovation. In this vein, we show that managerial mindfulness can affect corporate sustainable development. Using a sample of Chinese listed firms, we provide empirical support for our arguments. Therefore, our study can contribute to literature of mindfulness, as well as studies on TMT's influence on firm strategy and decision-making.

Author Contributions: Y.H. contributed to study design. Y.C. contributed to data collection and interpretation of the findings. X.Z. contributed to drafting the manuscript. All authors read, revised, and approved the final manuscript. 
Funding: This research was funded by National Natural Science Foundation of China (grant no. 71632007) and National Natural Science Foundation of China (grant no. 71672127).

Conflicts of Interest: The authors declare no conflict of interest.

\section{References}

1. Zang, Z.; Zhu, Q.; Mogorrón-Guerrero, H. How Does R\&D Investment Affect the Financial Performance of Cultural and Creative Enterprises? The Moderating Effect of Actual Controller. Sustainability 2019, 11, 297.

2. Chen, L.; Chen, Z.; Li, J. Can Trade Credit Maintain Sustainable R\&D Investment of SMEs?-Evidence from China. Sustainability 2019, 11, 843.

3. Loredo, E.; Lopez-Mielgo, N.; Pineiro-Villaverde, G.; García-Álvarez, M.T. Utilities: Innovation and Sustainability. Sustainability 2019, 11, 1085. [CrossRef]

4. Omobhude, C.; Chen, S.H. The Roles and Measurements of Proximity in Sustained Technology Development: A Literature Review. Sustainability 2019, 11, 224. [CrossRef]

5. Lee, C.Y. Industry R\&D intensity distributions: Regularities and underlying determinants. J. Evol. Econ. 2002, 12, 307-341.

6. Cohen, W.M. Fifty years of empirical studies of innovative activity and performance. In Handbook of the Economics of Innovation; Elsevier: North-Holland, The Netherlands, 2010; Volume 1, pp. 129-213.

7. Kor, Y.Y. Direct and interaction effects of top management team and board compositions on R\&D investment strategy. Strateg. Manag. J. 2006, 27, 1081-1099.

8. Christensen, D.M.; Dhaliwal, D.S.; Boivie, S.; Graffin, S.D. Top management conservatism and corporate risk strategies: Evidence from managers' personal political orientation and corporate tax avoidance. Strateg. Manag. J. 2015, 36, 1918-1938. [CrossRef]

9. Bromiley, P.; Rau, D.; Zhang, Y. Is R \& D risky? Strateg. Manag. J. 2017, 38, 876-891.

10. Zheng, X.; Xie, Q. The world's top 500 are meditating. What about you? Tsinghua Bus. Rev. 2015, 14-19.

11. Good, D.J.; Lyddy, C.J.; Glomb, T.M.; Bono, J.E.; Brown, K.W.; Duffy, M.K.; Baer, R.A.; Brewer, J.A.; Lazar, S.W. Contemplating mindfulness at work: An integrative review. J. Manag. 2016, 42, 877-880. [CrossRef]

12. Brown, K.W.; Ryan, R.M. The benefits of being present: Mindfulness and its role in psychological well-being. J. Personal. Soc. Psychol. 2003, 84, 822-848. [CrossRef]

13. Baas, M.; Nevicka, B.; Ten Velden, F.S. Specific mindfulness skills differentially predict creative performance. Personal. Soc. Psychol. Bull. 2014, 40, 1092-1106. [CrossRef] [PubMed]

14. Bishop, S.R.; Lau, M.; Shapiro, S.; Carlson, L.; Anderson, N.D.; Carmody, J.; Devins, G. Mindfulness: A proposed operational definition. Clin. Psychol. Sci. Pract. 2004, 11, 230-241. [CrossRef]

15. Park, T.; Reilly-Spong, M.; Gross, C.R. Mindfulness: A systematic review of instruments to measure an emergent patient-reported outcome (PRO). Qual. Life Res. 2013, 22, 2639-2659. [CrossRef] [PubMed]

16. Quaglia, J.T.; Brown, K.W.; Lindsay, E.K.; Creswell, J.D.; Goodman, R.J. From conception to operationalization of mindfulness. In Handbook of Mindfulness: Theory, Research, and Practice; Brown, K.W., Creswell, J.D., Ryan, R.M., Eds.; The Guilford Press: New York, NY, USA, 2015; pp. 151-170.

17. Hambrick, D.C.; Mason, P.A. Upper echelons: The organization as a reflection of its top managers. Acad. Manag. Rev. 1984, 9, 193-206. [CrossRef]

18. Finkelstein, S.; Hambrick, D.C. Top-management-team tenure and organizational outcomes: The moderating role of managerial discretion. Adm. Sci. Q. 1990, 35, 484-503. [CrossRef]

19. Wiersema, M.F.; Bantel, K.A. Top management team demography and corporate strategic change. Acad. Manag. J. 1992, 35, 91-121.

20. Hambrick, D.C.; Cho, T.S.; Chen, M.J. The influence of top management team heterogeneity on firms' competitive moves. Adm. Sci. Q. 1996, 41, 659-684. [CrossRef]

21. Knight, D.; Pearce, C.L.; Smith, K.G.; Olian, J.D.; Sims, H.P.; Smith, K.A.; Flood, P. Top management team diversity group process, and strategic consensus. Strateg. Manag. J. 1999, 20, 445-465. [CrossRef]

22. Hu, Y.; Chen, S.; Wang, J. Managerial Humanistic Attention and CSR: Do Firm Characteristics Matter? Sustainability 2018, 10, 4029. [CrossRef]

23. Wiseman, R.M.; Gomez-Mejia, L.R. A behavioral agency model of managerial risk taking. Acad. Manag. Rev. 1998, 23, 133-153. [CrossRef] 
24. Cohen, W.M.; Levinthal, D.A. Absorptive capacity: A new perspective on learning and innovation. Adm. Sci. Q. 1990, 35, 39-67. [CrossRef]

25. Greve, H.R.; Taylor, A. Innovations as catalysts for organizational change: Shifts in organizational cognition and search. Adm. Sci. Q. 2000, 45, 54-80. [CrossRef]

26. Shapiro, S.L.; Carlson, L.E.; Astin, J.A.; Freedman, B. Mechanisms of mindfulness. J. Clin. Psychol. 2006, 62, $373-386$. [CrossRef]

27. Glomb, T.M.; Duffy, M.K.; Bono, J.E.; Yang, T. Mindfulness at Work. In Research in Personnel and Human Resources Management; Emerald Group Publishing Limited: Bingley, UK, 2011; Volume 30, pp. 115-157.

28. Davis, J.H.; Schoorman, F.D.; Donaldson, L. Toward a stewardship theory of management. Acad. Manag. Rev. 1997, 22, 20-47. [CrossRef]

29. Levesque, C.; Brown, K.W. Mindfulness as a moderator of the effect of implicit motivational self-concept on day-to-day behavioral motivation. Motiv. Emot. 2007, 31, 284-299. [CrossRef]

30. Ryan, R.M.; Deci, E.L. Self-determination theory and the facilitation of intrinsic motivation social development, and well-being. Am. Psychol. 2000, 55, 68-78. [CrossRef]

31. Weick, K.E.; Sutcliffe, K.M.; Obstfeld, D. Organizing for High Reliability: Processes of Collective Mindfulness. In Research in Organizational Behavior; Staw, B.M., Cummings, L.L., Eds.; JAI Press: Greenwich, CT, USA, 1999; pp. 81-123.

32. Brown, K.W.; Ryan, R.M.; Creswell, J.D. Mindfulness: Theoretical foundations and evidence for its salutary effects. Psychol. Inq. 2007, 18, 211-237. [CrossRef]

33. Jha, A.P.; Morrison, A.B.; Dainer-Best, J.; Parker, S.; Rostrup, N.; Stanley, E.A. Minds "at attention": Mindfulness training curbs attentional lapses in military cohorts. PLoS ONE 2015, 10, e0116889. [CrossRef]

34. Tan, C.M. Search Inside Yourself: The Unexpected Path to Achieving Success, Happiness (and World Peace); Harper One: New York, NY, USA, 2012.

35. West, C.P.; Dyrbye, L.N.; Rabatin, J.T.; Call, T.G.; Davidson, J.H.; Multari, A.; Shanafelt, T.D. Intervention to promote physician well-being job satisfaction, and professionalism: A randomized clinical trial. JAMA Intern. Med. 2014, 174, 527-533. [CrossRef]

36. Wolever, R.Q.; Bobinet, K.J.; McCabe, K.; Mackenzie, E.R.; Fekete, E.; Kusnick, C.A.; Baime, M. Effective and viable mind-body stress reduction in the workplace: A randomized controlled trial. J. Occup. Health Psychol. 2012, 17, 246. [CrossRef]

37. Black, D.S. Mindfulness research guide: A new paradigm for managing empirical health information. Mindfulness 2010, 1, 174-176. [CrossRef]

38. Weick, K.E.; Roberts, K.H. Collective mind in organizations: Heedful interrelating on flight decks. Adm. Sci. Q. 1993, 38, 357-381. [CrossRef]

39. Zhang, J.; Wu, C. The influence of dispositional mindfulness on safety behaviors: A dual process perspective. Accid. Anal. Prev. 2014, 70, 24-32. [CrossRef]

40. Ocasio, W. Attention to attention. Organ. Sci. 2011, 22, 1286-1296. [CrossRef]

41. Dreyfus, G. Is mindfulness present-centered and non-judgmental? A discussion of the cognitive dimensions of mindfulness. Contemp. Buddhism 2011, 12, 41-54. [CrossRef]

42. Ray, J.L.; Baker, L.T.; Plowman, D.A. Organizational mindfulness in business schools. Acad. Manag. Learn. Educ. 2011, 10, 188-203.

43. Katila, R.; Ahuja, G. Something old something new: A longitudinal study of search behavior and new product introduction. Acad. Manag. J. 2002, 45, 1183-1194.

44. Rosenkopf, L.; Nerkar, A. Beyond local search: Boundary-spanning 2001, exploration, and impact in the optical disk industry. Strateg. Manag. J. 2001, 22, 287-306. [CrossRef]

45. Castellion, G.; Markham, S.K. Perspective: New product failure rates: Influence of argumentum ad populum and self-interest. J. Prod. Innov. Manag. 2013, 30, 976-979. [CrossRef]

46. Crawford, C.M. Marketing research and the new product failure rate. J. Mark. 1977, 41, 51-61. [CrossRef]

47. Gourville, J.T. Eager sellers and stony buyers: Understanding the psychology of new-product adoption. Harv. Bus. Rev. 2006, 84, 98-106, 145.

48. Masicampo, E.J.; Baumeister, R.F. Relating mindfulness and self-regulatory processes. Psychol. Inq. 2007, 18, $255-258$. [CrossRef]

49. Papies, E.K.; Barsalou, L.W.; Custers, R. Mindful attention prevents mindless impulses. Soc. Psychol. Personal. Sci. 2012, 3, 291-299. [CrossRef] 
50. Kirk, U.; Brown, K.W.; Downar, J. Adaptive neural reward processing during anticipation and receipt of monetary rewards in mindfulness meditators. Soc. Cogn. Affect. Neurosci. 2015, 10, 752-759. [CrossRef]

51. BarNir, A.; Gallaugher, J.M.; Auger, P. Business process digitization strategy, and the impact of firm age and size: The case of the magazine publishing industry. J. Bus. Ventur. 2003, 18, 789-814. [CrossRef]

52. Hannan, M.T.; Freeman, J. Structural inertia and organizational change. Am. Sociol. Rev. 1984, 49, $149-164$. [CrossRef]

53. Smallwood, J.; Schooler, J.W. The science of mind wandering: Empirically navigating the stream of consciousness. Psychology 2015, 66, 487-518. [CrossRef]

54. Nohria, N.; Gulati, R. Is slack good or bad for innovation? Acad. Manag. J. 1996, 39, 1245-1264. [CrossRef]

55. Greve, H.R. Organizational Learning from Performance Feedback-A Behavioral Perspective on Innovation and Change; Cambridge University Press: New York, NY, USA, 2003.

56. Banalieva, E.R.; Eddleston, K.A.; Zellweger, T.M. When do family firms have an advantage in transitioning economies? Toward a dynamic institution-based view. Strateg. Manag. J. 2015, 36, 1358-1377. [CrossRef]

57. Fan, J.P.H.; Wong, T.J.; Zhang, T. Organizational Structure as a Decentralization Device: Evidence from Corporate Pyramids. 2007. Available online: https://dx.doi.org/10.2139/ssrn.963430 (accessed on 21 May 2019).

58. Qian, C.; Wang, H.; Geng, X.; Yu, Y. Rent appropriation of knowledge-based assets and firm performance when institutions are weak: A study of Chinese publicly listed firms. Strateg. Manag. J. Forthcom. 2017, 38, 892-911. [CrossRef]

59. Xia, J.; Ma, X.; Lu, J.W.; Yiu, D.W. Outward foreign direct investment by emerging market firms: A resource dependence logic. Strateg. Manag. J. 2014, 35, 1343-1363. [CrossRef]

60. Zhu, H.; Toru, Y. Contingent value of director identification: The role of government directors in monitoring and resource provision in an emerging economy. Strateg. Manag. J. 2016, 37, 1787-1807. [CrossRef]

61. Cohen, W.M.; Levinthal, D.A. Innovation and learning: The two faces of R \& D. Econ. J. 1989, 99, 569-596.

62. Dosi, G. Sources, procedures, and microeconomic effects of innovation. J. Econ. Lit. 1988, 26, 1120-1171.

63. Hülsheger, U.R.; Alberts, H.J.E.M.; Feinholdt, A.; Lang, J.W.B. Benefits of mindfulness at work: The role of mindfulness in emotion regulation, emotional exhaustion, and job satisfaction. J. Appl. Psychol. 2013, 98, 310-325. [CrossRef]

64. Kabat-Zinn, J. Mindfulness-based interventions in context: Past, present, and future. Clin. Psychol. Sci. Pract. 2003, 10, 144-156. [CrossRef]

65. Reb, J.; Narayanan, J.; Chaturvedi, S. Leading mindfully: Two studies on the influence of supervisor trait mindfulness on employee well-being and performance. Mindfulness 2014, 5, 36-45. [CrossRef]

66. Pennebaker, J.W.; Graybeal, A. Patterns of natural language use: Disclosure personality, and social integration. Curr. Dir. Psychol. Sci. 2001, 10, 90-93. [CrossRef]

67. Huang, C.L.; Chung, C.K.; Hui, N.; Lin, Y.C.; Seih, Y.T.; Chen, W.C.; Pennebaker, J.W. The development of the Chinese linguistic inquiry and word count dictionary. Chin. J. Psychol. 2012, 54, 185-201.

68. Voss, G.B.; Sirdeshmukh, D.; Voss, Z.G. The effects of slack resources and environmental threat on product exploration and exploitation. Acad. Manag. J. 2008, 51, 147-164. [CrossRef]

69. Chang, Y.C. Benefits of co-operation on innovative performance: Evidence from integrated circuits and biotechnology firms in the UK and Taiwan. RD Manag. 2003, 33, 425-437. [CrossRef]

70. Leiponen, A. Organization of knowledge and innovation: The case of Finnish business services. Ind. Innov. 2005, 12, 185-203. [CrossRef]

71. Boyd, B.K. CEO duality and firm performance: A contingency model. Strateg. Manag. J. 1995, 16, $301-312$. [CrossRef]

72. Aiken, L.S.; West, S.G. Multiple Regression: Testing and Interpreting Interactions; Sage: Thousand Oaks, CA, USA, 1991.

73. Di Fabio, A. The psychology of sustainability and sustainable development for well-being in organizations. Front. Psychol. 2017, 8, 1534. [CrossRef]

74. Zhao, X.; Chen, S.; Xiong, C. Organizational attention to corporate social responsibility and corporate social performance: The moderating effects of corporate governance. Bus. Ethics A Eur. Rev. 2016, 25, 386-399. [CrossRef]

(C) 2019 by the authors. Licensee MDPI, Basel, Switzerland. This article is an open access article distributed under the terms and conditions of the Creative Commons Attribution (CC BY) license (http://creativecommons.org/licenses/by/4.0/). 